\title{
Pengaruh Motivasi Pembelajaran Jarak Jauh Terhadap Prestasi Belajar di Masa Pandemi Covid-19
}

\author{
Kinanti Prameswari ${ }^{1)}$, Supriyadi $^{2}$ \\ ${ }^{1)}$ Program Studi Pendidikan Ekonomi, Fakultas Ilmu Pendidikan, Universitas Panca Sakti Bekasi \\ ${ }^{2)}$ Program Studi Pendidikan Ekonomi, Fakultas Ilmu Pendidikan, Universitas Panca Sakti Bekasi
}

Corresponden author: supriyadiesbe@gmail.com

Received : 25 Februari $2021 \quad$ Accepted : 25 Maret 2021

Published: 30 Maret 2021

DOI: https://doi.org/10.37012/jipmht.v5i1.566

\begin{abstract}
ABSTRAK
Proses pendekatan dalam kegiatan belajar mengajar merupakan suatu hal yang sangat perlu untuk menarik siswa agar motivasi belajar meningkat. Hal ini perlu diupayakan peningkatan motivasi belajar siswa dalam masa pandemi covid-19 ini, karena akan berpengaruh terhadap prestasi belajar IPS di sekolah. Penelitian ini bertujuan untuk mengungkap: "Pengaruh Motivasi Belajar Terhadap Prestasi Belajar IPS Kelas IX SMP Islam Al-Ikhlas Pondokgede Dalam Pembelajaran Jarak Jauh Di Masa Pandemi Covid-19". Penelitian yang digunakan merupakan penelitian kuantitatif dengan pendekatan survei, Populasi penelitian ini adalah siswa kelas IX SMP Islam Al-Ikhlas Pondokgede di Kota Bekasi yang berjumlah 65. Jumlah sampel penelitian merujuk pada tabel Isaac \& Michael dengan signifikansi $10 \%$ sebanyak 52. Data penelitian diperoleh dengan menggunakan instrumen yang valid dan reliabel. Analisis data menggunakan analisis regresi sederhana. Disimpukan bahwa Prestasi Belajar ilmu pengetahuan sosial (IPS) siswa dipengaruhi oleh Motivasi Belajar peserta didik, Hal ini dapat dilihat dari perhitungan anova sederhana didapat nilai p-value lebih kecil dari 0,05 dengan demikian Ho ditolak, regresi $\mathrm{Y}$ atau X adalah signifikan atau Motivasi Belajar berpengaruh terhadap Prestasi Belajar IPS, dengan persamaan $\mathrm{Y}=1,188+0,986 \mathrm{X}$, demikian hipotesis penelitian didukung oleh data empiris
\end{abstract}

Kata Kunci: Motivasi, Prestasi Belajar, dan Pembelajaran Jarak Jauh.

\begin{abstract}
The approach process in teaching and learning activities is something that is very necessary to attract students so that learning motivation increases. It is necessary to strive to increase students' learning motivation during this covid-19 pandemic, because it will affect social studies learning achievement in schools. This study aims to reveal: "The Influence of Learning Motivation on Social Studies Learning Achievement for Class IX Islamic Junior High School Al-Ikhlas Pondokgede in Distance Learning During the Covid-19 Pandemic". The research used is a quantitative research with a survey approach. The population of this research is the class IX students of SMP Islam Al-Ikhlas Pondokgede in Bekasi City, totaling 65. The number of research samples refers to Isaac \& Michael table with a significance of $10 \%$ as many as 52. using valid and reliable instruments. Data analysis used simple regression analysis. It was concluded that the social science (IPS) learning achievement of students was influenced by students' learning motivation. It can be seen from the simple ANOVA calculation that the p-value is smaller than 0.05, thus Ho is rejected, Y or X regression is significant or Motivation Learning has an effect on Social Studies learning achievement, with the equation $Y=1.188+0.986 \mathrm{X}$, thus the research hypothesis is supported by empirical data.
\end{abstract}

Keywords: Motivation, Learning Achievement and Distance Learning. 


\section{PENDAHULUAN}

Pandemic COVID-19 adalah peristiwa menyebarnya penyakit korona virus 2019 (bahasa Inggris: corona virus disease 2019, disingkat COVID-19) di seluruh dunia. Penyakit ini disebabkan oleh koronavirus jenis baru yang diberi nama SARS-CoV-2. Wabah COVID-19 pertama kali dideteksi di Kota Wuhan, Provinsi Hubei, Tiongkok pada bulan Desember 2019, dan ditetapkan sebagai pandemi oleh Organisasi Kesehatan Dunia (WHO) pada 11 Maret 2020. Hingga 23 April 2020, lebih dari 2.000.000 kasus COVID-19 telah dilaporkan di lebih dari 210 negara dan wilayah, mengakibatkan lebih dari 195,755 orang meninggal dunia dan lebih dari 781,109 orang sembuh. Virus SARS-CoV-2 diduga menyebar di antara orang-orang terutama melalui percikan pernapasan (droplet) yang dihasilkan selama batuk. Percikan ini juga dapat dihasilkan dari bersin dan pernapasan normal. Selain itu, virus dapat menyebar akibat menyentuh permukaan benda yang terkontaminasi dan kemudian menyentuh wajah seseorang. Penyakit COVID -19 paling menular saat orang yang menderitanya memiliki gejala, meskipun penyebaran mungkin saja terjadi sebelum gejala muncul. Periode waktu antara paparan virus dan munculnya gejala biasanya sekitar lima hari, tetapi dapat berkisar dari dua hingga empat

COVID-19, merupakan varians dari virus-virus yang pernah melanda di dunia seperti SARS, flu burung, Flu babi, dan MERS namun yang membedakan adalah mudah menular,transparansi informasi, kekuarangan pasokan bagi tenaga medis, masalah inkubasi virus tidak jelas, karantina bersakala besar, dan "infodemic" yang unik, yaitu banyaknya informasi di media sosial yang menyebabkan pengaruh psikologis pada banyak orang (Dong \& Bouey, 2020). Dalam hitungan bulan saja, virus ini sudah menyebar ke seluruh negara di dunia. Di Indonesia, hampir semua provinsi telah terdeteksi kasus COVID-19. Selain itu, dampak COVID -19 itu begitu dashyat. Dampaknya yang nyata adalah kehilangan nyawa atau kematian, penurunan dan pelambatan ekonomi (resesi), terganggu aktivitas pendidikan, ekonomi dan sosial, dan yang paling mengkhawatir dampak psikologis dan perubahan perilaku pada masyarakat.

Pendidikan sangat penting artinya, sebab tanpa pendidikan manusia akan sulit berkembang dan bahkan akan terbelakang. Dengan demikian pendidikan harus betul-betul diarahkan untuk menghasilkan manusia yang berkualitas dan mampu bersaing, di samping memiliki budi pekerti yang luhur dan moral yang baik.

Untuk menghasilkan manusia yang berkualitas, pemerintah telah menggariskan dalam bab II pasal 3 Undang-undang Sistem Pendidikan Nasional Nomor 20 Tahun 2003 tentang tujuannya bahwa: pendidikan nasional berfungsi mengembangkan kemampuan dan 
membentuk watak serta peradaban bangsa yang bermartabat dalam rangka mencerdaskan kehidupan bangsa, bertujuan untuk berkembangnya potensi peserta didik agar menjadi manusia yang beriman dan bertakwa kepada Tuhan Yang Maha Esa, berakhlak mulia, sehat, berilmu, cakap, kreatif, mandiri, dan menjadi warga Negara yang demokratis, serta bertanggung jawab.

Semenjak diberlakukannya masa darurat Covid-19 pada tanggal 16 Maret 2020, hampir seluruh sekolah di Indonesia terutama di Kota Bekasi yang di tetapkan pada surat edaran Wali Kota Bekasi Nomor:443/2024/SETDA.Kessos Tentang Peningkatan Kewaspadaan Kesiapsiagaan Menghadapi Infeksi Virus Corona (COVID-19) telah mengambil kebijakan untuk pembelajaran daring atau disebut dengan pembelajaran jarak jauh (PJJ). Dengan adanya pembelajaran daring guru dan peserta didik sama-sama belajar untuk memanfaatkan teknologi sebagai media pembelajaran. Dalam melaksanakan pembelajaran daring dengan berbagai keterbatasan kemampuan, sarana dan prasarana berupa handphone, laptop dan jaringan bagi guru dan peserta didik serta kemampuan yang masih terbatas dalam pemanfaatan teknologi membuat pelaksanaan pembelajaran daring harus tetap diupayakan berjalan agar proses transformasi ilmu pengetahuan kepada peserta didik tidak terganggu.

Menurut MacKenzie, Christensen, \& Rigby, (1968) (dalam Paulina Pannen, 1999): Pembelajaran Jarak Jauh ( PJJ) adalah suatu metode pembelajaran yang menggunakan korespondensi sebagai alat komunikasi antara tenaga pengajar dengan peserta didik, ditambah dengan adanya interaksi antar peserta didik dalam proses pembelajaran. Maka dari itu guru menggunakan aplikasi pembelajaran dalam laptop nya atau handphone untuk melakukan kegiatan belajar mengajar seperti google classroom, zoom dan whatsapp grup.

Motivasi belajar adalah dorongan atau kekuatan dalam diri siswa yang menimbulkan kegiatan serta arah belajar untuk mencapai tujuan yang dikehendaki siswa. Menurut Rusman $(4,23)$, sumber motivasi dalam belajar dapat dibedakan menjadi dua jenis, yaitu: 1. Motivasi intrinsik adalah tenaga pendorong yang sesuai dengan perbuatan yang dilakukan. Motivasi intrinsik adalah motif-motif yang menjadi aktif atau berfungsinya tidak perlu dirangsang dari luar, karena di dalam diri setiap individu sudah ada dorongan untuk melakukan sesuatu. 2. Motivasi ekstrinsik adalah tenaga pendorong yang ada di luar perbuatan yang dilakukannya, tetapi menjadi penyerta. Motivasi ekstrinsik adalah motif-motif yang aktif atau berfungsinya karena adanya rangsangan dari luar. Prestasi belajar dapat dikatakan sebagai seluruh kecakapan atau perubahan tingkah laku yang dicapai melalui proses belajar berdasarkan tes prestasi yang dilakukan dan hasilnya dituangkan dalam bentuk nilai ulangan, ujian, atau rapor yang 
diraihnya. Untuk itu semua siswa harus berusaha semaksimal mungkin agar dapat memperoleh hasil atau prestasi belajar yang optimal. Tinggi rendahnya prestasi belajar tergantung dari usaha masing-masing individu. Syamsudin (1999:160), Prestasi belajar adalah kecakapan nyata atau actual ability, yaitu kecakapan yang segera dapat didemonstrasikan dan diuji sekarang juga karena merupakan hasil usaha atau belajar yang bersangkutan dengan teknik tertentu yang telah dijalaninya. Banyak penelitian-penelitian yang mengungkap tentang motivasi dan prestasi belajar IPS siswa yang menarik dalam penelitian ini adalah motivasi siswa yang dimaksud adalah motivasi yang dilakukan saat pembelajaran jarak jauh dan dilakukan pada masa pandemi covid-19 dimana seluruh pembelajaran dilakukan melalui daring. Penelitian ini bertujuan untuk mengungkap: "Pengaruh Motivasi Belajar Terhadap Prestasi Belajar IPS Kelas IX SMP Islam Al-Ikhlas Pondokgede dalam Pembelajaran Jarak Jauh di Masa Pandemi Covid19 ".

\section{METODE}

Penelitian ini merupakan penelitian kuantitatif dengan pendekatan survei dengan teknik analisis regresi sederhana. Berikut konstelasi penelitian:

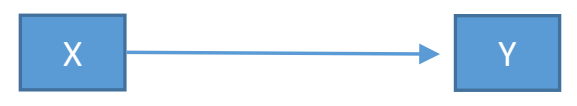

Keterangan:

$\mathrm{X}=$ Variabel Motivasi Belajar

$\mathrm{Y}=$ Variabel Prestasi Belajar

Penelitian ini dilakukan pada siswa kelas IX SMP Islam Al-Ikhlas Pondokgede. Tahapan pelaksanaan dalam penelitian ini berlangsung selama 3 bulan mulai dari Januari sampai Maret 2021. Jumlah sampel penelitian merujuk pada tabel Isaac \& Michael dengan signifikansi 1\% sebanyak 65 siswa kelas IX, menggunakan teknik random sampling. Pengumpulan data berupa skor diambil dengan menggunakan instrumen motivasi belajar dalam bentuk instrumen skala sikap dan skor prestasi belajar diambil dari nilai raport semester Gasal tahun pelajaran 20202021 untuk mata pelajaran IPS. Penelitian ini dilakukan pada semester genap tahun pelajaran 2020/2021. Instrumen motivasi belajar valid dan memiliki reliabilitas Alpha dimensi I 0,912, dan dimensi II 0.831. Teknik analisis data menggunakan analisis regresi sederhana dimana prestasi belajar sebagai variabel terikat (Y) untuk motivasi belajar sebagai variabel bebas (X). Hipotesa penelitian ini: motivasi belajar berpengaruh terhadap prestasi belajar siswa dimasa 
COVID-19. Analisis data penelitian dilakukan dengan menggunakan software program SPSS 20, dengan terlebih dahulu mendeskripsikan data hasil penelitian, selanjutnya dilakukan uji prasyarat dengan menguji normalitas dengan uji one sample kolmogorov smirnov dan homogenitas data dengan uji levene, setelah didapatkan data yang normal dan homogen dilanjutkan dengan uji hipotesis dengan analisis regresi sederhana.

\section{HASIL DAN PEMBAHASAN}

\section{Hasil dan Pembahasan}

Deskripsi data skor Variabel motivasi belajar dan prestasi belajar Siswa disajikan pada tabel berikut:

\section{Skor Prestasi Belajar IPS}

Skor prestasi belajar yang diperoleh dari tempat penelitian dianalisis dengan menggunakan SPSS 20 didapat hasil analisis sebagai berikut:

Tabel 1.

Deskripsi Data Skor Variabel

\begin{tabular}{lcc}
\hline \multicolumn{2}{l}{ Statistics } \\
\hline Prestasi & \\
\hline \multirow{2}{*}{$\mathbf{N}$} & \multicolumn{1}{c}{ Valid } & $\mathbf{5 2}$ \\
\cline { 2 - 3 } & Missing & $\mathbf{0}$ \\
\hline Mean & 87.75 \\
\hline Std. Error of Mean & .343 \\
\hline Median & 88.00 \\
\hline Mode & 88 \\
\hline Std. Deviation & 2.472 \\
\hline Variance & 6.113 \\
\hline Range & 11 \\
\hline Minimum & 84 \\
\hline Maximum & 95 \\
\hline Sum & 4563 \\
\hline
\end{tabular}

Berdasarkan skor Prestasi Belajar IPS sebayak 52 responden dari siswa kelas IX di SMP AlIkhlas, diperoleh skor empirik terendah 84 dan skor empirik tertinggi 95. rentang skor 30. Ratarata skor (mean) sebesar 87.79 simpangan baku 2.472 modus 85 , median 88.00

\section{Skor Motivasi Belajar}

Berdasarkan skor motivasi belajar IPS sebanyak 52 responden siswa kelas IX di SMP Al-Ikhlas, diperoleh skor empirik terendah 84 dan skor empirik tertinggi 95, rentang skor 11, Rata-rata 
skor (mean) sebesar 88.4762 simpangan baku 2.492, modus 88 , median 88 variance 6.209 dan total skor 4565 .

Tabel 2.

Deskripsi Data Skor Variabel

\begin{tabular}{lcc}
\hline \multicolumn{2}{l}{ Statistics } \\
\hline Motivasi & & \\
\hline \multirow{2}{*}{$\mathbf{N}$} & \multicolumn{1}{c}{ Valid } & $\mathbf{5 2}$ \\
\cline { 2 - 3 } & Missing & $\mathbf{0}$ \\
\hline Mean & 87.79 \\
Std. Error of Mean & & .346 \\
Median & 88.00 \\
Mode & $88^{\mathrm{a}}$ \\
Std. Deviation & 2.492 \\
Variance & 6.209 \\
Range & 11 \\
Minimum & & 84 \\
Maximum & & 95 \\
Sum & & 4565 \\
\hline
\end{tabular}

\section{Pengujian Persyaratan Analisis Data}

\section{Uji Normalitas}

Untuk mengetahui apakah data yang penulis kumpulkan dan diteliti termasuk data berdistribusi normal atau tidak, maka penulis melakukan pengujian dengan menggunakan alat bantuan software yaitu SPSS versi 20 yang hasilnya dapat dilihat pada table berikut:

a. Uji Normalitas Skor Prestasi Belajar

Tabel 3.

Uji Prasyarat Uji Normalitas Data

\begin{tabular}{llc}
\hline \multicolumn{3}{c}{ One-Sample Kolmogorov-Smirnov Test } \\
\hline \multicolumn{1}{c}{$\mathbf{N}$} & \multicolumn{1}{c}{ Prestasi } \\
\hline \multirow{2}{*}{ Normal Parameters ${ }^{\mathrm{a}, \mathrm{b}}$} & \multicolumn{1}{c}{$\mathbf{5 2}$} \\
\cline { 2 - 3 } & Mean & 87.75 \\
\hline \multirow{3}{*}{ Most Extreme Differences } & Std. Deviation & 2.472 \\
\cline { 2 - 3 } & Absolute & .156 \\
\cline { 2 - 3 } & Positive & .152 \\
\hline Kolmogorov-Smirnov Z & & -.156 \\
\hline Asymp. Sig. (2-tailed) & & .122 \\
\hline & \\
\hline $\begin{array}{l}\text { a. Test distribution is Normal. } \\
\text { b. Calculated from data. }\end{array}$ \\
\hline
\end{tabular}


Dari data di atas, diperoleh Kolmogorov-SmimovZ sebesar 1.122 angka ini sama dengan hasil secara manual dan nilai Asymp. Sig. (2-tailed) sebesar 0,161 atau dapat ditulis sebagai nilai probabilitas $(\mathrm{p}$-value $)=0,161>0,05$ atau Ho diterima. Dengan demikian, data prestasi belajar IPS berdistribusi Normal.

b. Uji Normalitas Skor Motivasi Belajar

Tabel 4.

Uji Prasyarat Uji Normalitas Data

One-Sample Kolmogorov-Smirnov Test

\begin{tabular}{llc} 
& & Motivasi \\
\hline \multicolumn{1}{c}{$\mathbf{N}$} & $\mathbf{5 2}$ \\
\hline Normal Parameters $^{\mathrm{a}, \mathrm{b}}$ & Mean & 87.79 \\
\hline & Std. Deviation & 2.492 \\
\hline Most Extreme Differences & Absolute & .149 \\
\hline & Positive & .149 \\
& Negative & -.149 \\
\hline Kolmogorov-Smirnov Z & & 1.076 \\
\hline Asymp. Sig. (2-tailed) & .197 \\
\hline \multicolumn{3}{l}{} \\
\hline a. Test distribution is Normal. \\
b. Calculated from data. \\
\hline
\end{tabular}

Dari data di atas, diperoleh Kolmogorov-SmimovZ sebesar 1.076, angka ini sama dengan hasil secara manual dan nilai Asymp. Sig. (2-tailed) sebesar 0,197 atau dapat ditulis sebagai nilai probabilitas (p-value) $=0,197>0,05$ atau Ho diterima. Dengan demikian, data Motivasi Belajar IPS berdistribusi Normal.

\section{Uji Homogenitas}

Uji homogenitas dilakukan dengan maksud untuk mengetahui apakah sebaran data dari setiap variable tidak menyimpang dari ciri-ciri data yang homogen pengujian homogenitas dilakukan terhadap varian regresi dependen atau variable-variabel independen dengan menggunakan statistic. 
Tabel 5.

Uji Prasayarat Uji Homogenitas

\begin{tabular}{cccc}
\hline \multicolumn{4}{c}{ Levene's Test of Equality of Error Variances $^{\mathbf{a}}$} \\
\hline Dependent Variable: Skor & & & \\
\hline F & df1 & df2 & Sig. \\
\hline .010 & 1 & 102 & .921 \\
\hline
\end{tabular}

Tests the null hypothesis that the error variance of the dependent variable is equal across groups. ${ }^{\mathrm{a}}$

a. Design: Intercept + Kelompok

Dari hasil analisis pada tabel Test of Homogeneity of Variances,diperoleh Levene Statistic $=0,010 ;$ df $1=1 ;$ df2 $=102$, dan p-value $=, 921>0,05$ atau Ho diterima. Dengan demikian, kedua kelompok data berasal dari kelompok yang homogen.

\section{Uji Hipotesis}

Hasil uji hipotesis dengan menggunakan SPSS 20 sebagai berikut:

Tabel 6.

Coefficients $^{\mathrm{a}}$

\begin{tabular}{cllccccc}
\hline \multirow{2}{*}{ Model } & \multicolumn{2}{c}{ Unstandardized Coefficients } & \multicolumn{3}{c}{$\begin{array}{c}\text { Standardized } \\
\text { Coefficients }\end{array}$} & t & Sig. \\
& & & \multicolumn{2}{c}{ Std. } & Beta & & \\
\hline \multirow{2}{*}{1} & & B Constant) & 1.188 & 1.371 & & .866 & .391 \\
& Motivasi & .986 & .016 & .994 & 63.142 & .000 \\
\hline
\end{tabular}

a. Dependent Variable: Prestasi

Diperoleh dari kolom B, sehingga persamaan regresi: $\mathrm{Y}=1,188+0,986 \mathrm{X}$. Dari hasil analisis diperoleh $t_{\text {hit }}=63.142$ dan p-value $=0,000 / 2=0<0,05$ atau Ho ditolak. Dengan demikian. Motivasi belajar berpengaruh positif

Tabel 7.

ANOVA

\begin{tabular}{|c|c|c|c|c|c|c|c|}
\hline & & & $\begin{array}{c}\text { Sum of } \\
\text { Squares }\end{array}$ & df & $\begin{array}{c}\text { Mean } \\
\text { Square } \\
\end{array}$ & $\mathbf{F}$ & Sig. \\
\hline \multirow{5}{*}{$\begin{array}{c}\text { Prestasi * } \\
\text { Motivasi }\end{array}$} & \multirow{3}{*}{$\begin{array}{c}\text { Between } \\
\text { Groups }\end{array}$} & (Combined) & 308.017 & 5 & 61.603 & 759.041 & .000 \\
\hline & & Linearity & 307.889 & 1 & 307.889 & 3.793 .629 & .000 \\
\hline & & $\begin{array}{l}\text { Deviation } \\
\text { from } \\
\text { Linearity }\end{array}$ & .128 & 4 & .032 & .394 & .812 \\
\hline & \multirow{2}{*}{\multicolumn{2}{|c|}{$\begin{array}{c}\text { Within Groups } \\
\text { Total }\end{array}$}} & 3.733 & 46 & .081 & & \\
\hline & & & 311.750 & 51 & & & \\
\hline
\end{tabular}


Hipotesis statistik:

Ho : $\mathrm{Y}=\mathrm{a}+\mathrm{Bx}$ (regresi linear)

Ho : $\mathrm{Y}=\mathrm{a}+\mathrm{Bx}$ (regresi tak linear)

Tabel 8.

ANOVA $^{\mathrm{a}}$

\begin{tabular}{|c|c|c|c|c|c|c|}
\hline \multicolumn{2}{|c|}{ Model } & $\begin{array}{c}\text { Sum of } \\
\text { Squares }\end{array}$ & df & $\begin{array}{c}\text { Mean } \\
\text { Square }\end{array}$ & $\mathbf{F}$ & Sig. \\
\hline \multirow[b]{2}{*}{1} & Regression & 307.889 & 1 & 307.889 & 3.986 .855 & $.000^{b}$ \\
\hline & $\begin{array}{l}\text { Residual } \\
\text { Total }\end{array}$ & $\begin{array}{c}3.861 \\
311.750\end{array}$ & $\begin{array}{l}50 \\
51\end{array}$ & .077 & & \\
\hline
\end{tabular}

Uji linearitas persamaan garis regresi diperoleh dari baris Deviation from Linearity, yaitu Fhit $(\mathrm{TC})=0,394$, dengan $\mathrm{p}$-value $=0,812>0,05$. Hal ini berarti Ho diterima atau persamaan regresi $\mathrm{Y}$ atas $\mathrm{X}$ adalah linear atau berupa garis linear.

a. Dependent Variable: Prestasi

b. Predictors: (Constant), Motivasi

Hipotesis statistik:

Ho $: b=0$ (regresi tak berarti)

Hi : b $=0$ (regresi berarti)

Uji signifikansi persamaan persamaan garis regresi diperoleh dari baris regression kolom ke-5, yaitu $\mathrm{F}$ hit $(\mathrm{b} / \mathrm{a})=3986.855$, dan $\mathrm{p}$-value $=0,000<0,05$ atau Ho ditolak. Dengan demikian, regresi $\mathrm{Y}$ atau $\mathrm{X}$ adalah signifikan atau motivasi belajar berpengaruh terhadap Prestasi Belajar IPS, dengan demikian hipotesis penelitian didukung oleh data empiris.

Tabel 6.

Model Summary

\begin{tabular}{cccccccc}
\hline Model & R & R Square & $\begin{array}{c}\text { Adjusted } \\
\text { R Square }\end{array}$ & $\begin{array}{c}\text { Std. } \\
\text { Error of } \\
\text { the } \\
\text { Estimate }\end{array}$ & $\begin{array}{c}\text { Change Statistics } \\
\text { R Square } \\
\text { Change }\end{array}$ & F Change & df1 \\
\hline 1 & $.994^{\mathrm{a}}$ & .988 & .987 & .278 & .988 & 3.986 .855 & 1 \\
\hline
\end{tabular}

Uji signifikansi koefisien korelasi diperoleh dari tabel Model Summary. Terlihat pada baris pertama koefisien korelasi $(\mathrm{r} x y)=0,987$ dan $\mathrm{F}$ hit $(\mathrm{F}$ change $)=3986,855$, dengan $\mathrm{p}$-value $=$ $0,000<0,05$. Hal ini berarti Ho ditolak. Dengan demikian, koefisien korelasi X dan Y adalah berarti atau signifikan. Sedangkan koefisien determinasi dari tabel di atas terlihat pada baris ke- 
2, yaitu R Square = 0,987, yang mengandung makna bahwa 98,7 \% variasi variabel Prestasi Belajar IPS dapat dipengaruhi oleh Motivasi Belajar IPS.

\section{Pengujian Hipotesis}

Untuk dapat memahami makna hasil penelitian secara menyeluruh, maka hasil analisis data penelitian di atas dapat diinterpretasikan sebagai berikut: Prestasi Belajar ilmu pengetahuan sosial (IPS) siswa dipengaruhi oleh Motivasi Belajar peserta didik,Hal ini dapat dilihat dari perhitungan anova sederhana didapat nilai p-value lebih kecil dari 0,05 dengan demikian Ho ditolak, regresi $\mathrm{Y}$ atau $\mathrm{X}$ adalah signifikan atau Motivasi Belajar berpengaruh terhadap Prestasi Belajar IPS, dengan persamaan $\mathrm{Y}=1,188+0,986 \mathrm{X}$, demikian hipotesis penelitian didukung oleh data empiris.

\section{Pembahasan}

Dari hasil pengujian hipotesa penelitian, menunjukkan bahwa hipotesis kerja penelitian ini dapat diterima.

Prestasi Belajar ilmu pengetahuan sosial (IPS) dipengaruhi oleh Motivasi Belajar peserta didik. Hal ini dapat dilihat dari perhitungan anova sederhana didapat nilai p-value lebih kecil dari 0,05 dengan demikian Ho ditolak, regresi $\mathrm{Y}$ atau $\mathrm{X}$ adalah signifikan atau Motivasi Belajar berpengaruh terhadap Prestasi Belajar IPS, dengan persamaan Y =1,188 +0,986 X, demikian hipotesis penelitian didukung oleh data empiris. Dengan adanya motivasi belajar, maka siswa akan terdorong untuk memperoleh perubahan dalam kehidupannya, yakin akan kepentingan dan mafaatnya dari belajar.

Hal ini sejalan dengan Slameto dalam Supriyadi (2018:25), mengemukakan belajar ialah suatu proses usaha yang dilakukan seseorang untuk memperoleh suatu perubahan tingkah laku yang baru secara keseluruhan, sebagai hasil pengalamannya sendiri dalam interaksi dengan lingkungannya.

Dengan demikian, apabila seorang guru ingin berhasil dalam melakukan kegiatan pembelajaran harus dapat memberikan rangsangan kepada siswa agar termotivasi dalam mengikuti proses kegiatan pembelajaran tersebut. Apabila siswa sudah merasa termotivasi mengikuti pelajaran, maka akan lebih semangat dan mengerti apa yang di sampaikan oleh guru, begitu juga sebaliknya apabila siswa merasakan tidak termotivasi dalam melakukan proses kegiatan pembelajaran ia akan merasa jenuh dan bosan dalam mengikuti pelajaran tersebut, mengembangkan motivasi terhadap sesuatu pada dasarnya adalah membantu siswa melihat bagaimana hubungan antara materi yang diharapkan untuk dipelajari dengan dirinya sendiri 
sebagai individu. Proses ini berarti menunjukan pada siswa bagaimana pengetahuan atau kecakapan tertentu mempengaruhi dirinya, melayani tujuannya untuk memuaskan kebutuhannya.

Hamdani (2011 : 138) yang mengatakan bahwa prestasi belajar yaitu hasil yang diperoleh berupa kesan - kesan yang mengakibatkan perubahan dalam diri individu sebagai hasil dari sebuah aktivitas.

Prestasi yang didapatkan oleh siswa sangat dipengaruhi oleh proses pembelajarannya, dari pembelajaran yang dilakukan terdapat motivasi untuk menghasilkan prestasi baik dalam hidupnya

Bila siswa menyadari bahwa belajar merupakan suatu alat untuk mencapat beberapa tujuan yang dianggap nya penting, dan bila siswa melihat bahwa hasil dari pengalaman belajarnya akan membawa kemajuan pada dirinya, kemungkinan besar ia akan termotivasi untuk mempelajarinya.

\section{SIMPULAN DAN REKOMENDASI}

Setelah data penelitian diperoleh dengan menggunakan instrument ukur yang disusun oleh peneliti, maka dilakukan analisis data secara kuantitif, hal ini dilakukan untuk menjawab masalah melalui pengujian terhadap hipotesis penelitian. Dari hasil pengujian hipotesis, maka dapat ditarik kesimpulan sebagai berikut: Prestasi Belajar ilmu pengetahuan sosial (IPS) siswa dipengaruhi oleh Motivasi Belajar peserta didik, Hal ini dapat dilihat dari perhitungan anava sederhana didapat nilai p-value lebih kecil dari 0,05 dengan demikian Ho ditolak, regresi Y atau $\mathrm{X}$ adalah signifikan atau Motivasi Belajar berpengaruh terhadap Prestasi Belajar IPS, dengan persamaan $\mathrm{Y}=1,188+0,986 \mathrm{X}$, demikian hipotesis penelitian didukung oleh data empiris. Hasil penelitian, dapat dikemukakan bahwa Motivasi Belajar IPS berpengaruh terhadap Prestasi Belajar IPS.

Dari hasil penelitian ini maka dapat direkomendasikan bahwa : Guru harus dapat menekankan pentingnya motivasi dalam setiap pembelajaran dan menyelesaikan tugas-tugas yang diberikan kepada siswa nya, untuk meningkatkan mutu pendidikan. 


\section{REFERENSI}

1. Alder, H. 2001. Boost Your Intelligence, terjemahan Kristina Prianingsih. Jakarta: Erlangga,. Anwar, S. 2010. Penyusunan Skala Psikologi. Yogyakarta: Pustaka Pelajar.

2. Arikunto, S. 2009. Manajemen Penelitian. Jakarta: PT Rieka Cipta.

3. Bloom, B.S. 1981. Taxonomy of Educational Objective. Handbook I. New York: Xongman Inc.

4. Kerlinger, F. N. 2006. Asas-Asas Penelitian Behavioral. Yogyakarta: Gadjah Mada University Press.

5. Supriyadi. 2018. Pengaruh Pendekatan Pembelajaran, Kecerdasan Emosional dan Kecerdasan Adversitas terhadap Hasil Belajar Videografi, Disertasi. Jakarta: Universitas Negeri Jakarta.

6. https://doi.org/10.37012/jipmht.v4i1.457 Intensitas Penggunaan Gawai Terhadap Kecerdasaan Emosional Mahasiswa.

7. http://jurnal.una.ac.id/index.php/jmp/article/view/1354 Analisis Motivasi Belajar Mahasiswa Menggunakan Video Pembelajaran Sebagai Alternatif Pembelajaran Jarak Jauh (Pjj)

8. https://journal.unnes.ac.id/nju/index.php/DP/article/view/4922 Pengaruh Motivasi Belajar Mahasiswa Dan Kompetensi Dosen Terhadap Prestasi Belajar

9. http://114.7.97.221/index.php/JAM/article/view/1822 Sosialisasi Inarisk Sebagai Upaya Pencegahan Dan Percepatan Penanganan Covid-19 Pada Masyarakat Kecamatan Medan Helvetia Kota Medan

10. http://ejournal.uin-suska.ac.id/index.php/Psikobuletin/article/view/9616/5058 Memahami Pandemi COVID-19 dalam Perspektif Psikologi Sosial 